\title{
NOTES ON APLYSIA
}

(Received April 7, 1958)

Eveline and Ernst Marcus

(Caixa Postal 6994, S. Paulo)

(With 4 plates)

The present paper contains the description of 1 specimen of Aplysia cervina (Dall \& Simpson, 1901) from the litoral of São Paulo and comparative remarks on the generative system of 3 further species of Aplysia occurring on the Brazilian coast.

The bibliographic state of A. cervina up to January 1958 is as follows:

? Tethys (Aplysia) pilsbryi Letson 1898, p. 193, t. 8, f. 1-4.

Tethys cervina Dall \& Simpson 1901, p. 365, t. 56, f. 2.

Tethys cervina MacFarland 1909, p. 38-57, f. 15-35, 39-42.

? Tethys cervina v. Ihering 1915 , p. 134, 140.

Aplysia cervina Engel \& Hummelinck 1936, p. 13.

Aplysia cervina Eales 1957, p. 246.

Occurrence: Island of Sebastião, $4 \mathrm{~km}$ west of Ilhabela. One adult specimen in shallow water; November 1957.

Further distribution: Charleston, South Carolina (Eales); ? northern coast of Yucatan (Letson); Mayaguez, Porto Rico (Dall \& Simpson);

Curaçao (Engel \& Hummelinck); Maceió, Alagoas (MacFarland); ? Bahia (v. Ihering). As far as there are indications, the slugs were taken in shallow water.

\section{Description of A. cervina}

The present sea-hare was about $10 \mathrm{~cm}$ long alive. The ground colour was greyish greenish, covered by a fine, superficial network of black pigment, which let the skin appear dark to the naked eye. More than 50 scattered dark brown, round spots, $2-3 \mathrm{~mm}$ in diameter, occurred on either side and were distinctly set off from the pigment net. Many white spots, single or in confluent groups, were surrounded by pigment-free halos. 
When narcotized with menthol the slug contracted its right side strongly and did not return to relaxation for several hours. It was killed in this state in seawater-formalin with only the left parapodium well relaxed. The following description and figures refer to the preserved slug (Fig. 1) after having remained in seawater-formalin for about 6 weeks.

The measurements, in mm, which are similar to those of Engel \& Hummelinck's specimen, are: length of body 70 , height 50 , breadth 40 , length of sole 60 , its breadth about 15 , in front 24 . Length of tail 6 , its tip rounded.

The dark elements of the colour are preserved. The white spots, evidently produced by secretion of epidermal glands, have disappeared as usually in preserved sea-hares. The pigment-free areae around these spots are salient. The inner side of the parapodia is pigmented, and this pigment is darker towards the margin, where it is interrupted by light bands radiating from the whitish border. The head is uniformly grey with a light seminal groove $(q)$; the sole is a little darker than the head. The thickness of the skin makes the eye pigment unrecognizable. The dorsal surface of the mantle is dark with light spots. With a lens a radiating dark pattern around the papilla of the mantle foramen is visible. Around the genital opening $(g)$ the pigment is denser. The gill $(z)$ is pale grey. Its upper side is darker, evidently due to a colouring from the adjoining purple gland $(y)$.

The tentacles form the ends of the buccal veil and are furrowed on the outside. The rhinophores are long and pointed, their furrow occupies only the upper half of their length. The sole is entire, not divided into more or less muscular areae (Subgenus Tullia). The parapodia have thin borders. They are separated in front by a distance of $5 \mathrm{~mm}$, behind they join low down, on the root of the foot. The minute opening $(\mathrm{m})$ into the shell cavity is borne upon a low papilla and almost closed in the present slug. The shell (Fig. 3) is decalcified; it is $29 \mathrm{~mm}$ long and $22 \mathrm{~mm}$ broad. The sinus is $15 \mathrm{~mm}$ long.

The purple gland $(y)$ covers an extense area of the roof of the mantle cavity. It consists of numerous cells of different sizes with separate orifices and dark contents. The yellowish opaline gland (oi) opens by a single aperture. The organ is curved, $15 \mathrm{~mm}$ long, $5 \mathrm{~mm}$ in diameter, and has sharp edges. MacFarland (1909, p. 56) described the opaline gland as spherical and with a diameter of $4 \mathrm{~mm}$ (t. 3, f. 17).

The jaw plates (Fig. 4) are as figured by MacFarland (t. 3, f. 15), hence different from the right-angled triangles of $A$. brasiliana (Marcus 1955 , t. 1, f. 3). Their anterior border is straight and the hind border convex; the breadth of each plate is $6,5 \mathrm{~mm}$ and their length, the anteroposterior extension, 3,5 mm. The lateral borders are of nearly equal length, and the cuticle between them is strengthened dorsally, as in $A$. juliana (Marcus 1958, f. 33). The rods (Fig. 5), which compose the jaw plates, are brown to black in front and become light yellow in the hind 
part. They are $\mathbf{0 , 1 5} \mathrm{mm}$ long in front and shorter behind; their diameter is 20 micra. They end straight, either blunt or pointed (MacFarland, f. 16), not as in brasiliana (Marcus 1955, f. 4) with a bent and denticulated tip.

The radula (Fig. 6) is $9,5 \mathrm{~mm}$ long and $7,5 \mathrm{~mm}$ broad. It has 46 rows of 30.1.30 plates. The 3 marginal plates are small and bear no cusp. Though Eales (1957, p. 246) mentioned a constricted plate of the rhachidian tooth and bulbous heads of the lateral teeth as characteristic of A. cervina, we did not succeed to find any specific characters in the radula. We compared our slide with radulae of brasiliana and juliana, as well as with MacFarland's figures of 24 plates of dactylomela (t. 1) and 73 of cervina (t. 4-5). It is true that the lateral margins of the central plate of cervina are sometimes a little more concave than in the other species, but the difference is slight and not even constant, if all rows from the earliest to the latest are considered. Also the variation of all other characters is great. For example, in the present radula the main cusp of the laterals is more slender than in MacFarland's drawings. Our first lateral plate is similar to his fourth (f. 24), our fifth to his tenth. The main cusp of the laterals bears hooks on both sides, and further cusps occur on the outer side of the main cusp. According to MacFarland (p. 42) their number is 2-3, rarely 4, but in the present slug there are 1-4, or even 5. Moreover MacFarland stressed that these cusps are smooth, but in our specimen the largest of them is sometimes denticulated.

Nor do the teeth of the gizzard offer specific characters. Also the pharynx and the salivary glands were not found to differ markedly from those of other species. The gastric valves $(v a)$ are symmetrical like those of brasiliana (Marcus 1955, p. 7-8, f. 9), hence not consistent with MacFarland's description (p. 45). The curled caecum (c) is clearly different from the straight one in brasiliana (Marcus 1955, f. 9), and its main direction is transverse, not longitudinal as in brasiliana. It corresponds to MacFarland's indication (p. 45) "a narrow curved cylindrical tube", but is much longer $(20 \mathrm{~mm})$ than that of his slug $(9 \mathrm{~mm})$. The tip of the caecum appears on the dorsal surface of the olive coloured liver $(v)$, inside the first loop of the intestine $(i)$. The course of the latter (Fig. 7) is more winding than in MacFarland's figure 31, which refers to a much smaller animal $(40 \mathrm{~mm})$.

The digestive tract contained great quantities of Rhodophyceae, which are perfectly intact in the crop $(k)$ and slightly triturated in the second gizzard $(s c)$. Immediately behind the opening of the caecum the gut contains so much sand that the algae do not appear. Farther behind the contents form loose flocs, and after the second bend these are united in thin sausage-shaped grey pellets, which fill the rest of the gut.

The reproductive organs (Fig. 8-9) are not fully developed, but their elements are all present and perhaps more clearly visible than in quite mature state (MacFarland 1909, p. 36), when the mucus gland $(d)$ overlaps other reproductive organs. After slight staining with paracarmine the 
hermaphrodite and female duct with all their coils and inner folds could easily be followed. They are similar to Eales' figures 18 and 20 (1921, t. 6) of A. punctata (Cuv.) and almost identical with MacFarland's figure 33 (t. 6) of A. cervina. While the spermatheca $(t)$ and the spermatocyst $(s)$ are still empty, the ampulla $(h)$ or little hermaphrodite duct is already filled with sperm. The spermoviduct $(l)$ or loop of the little hermaphrodite duct enters the fertilisation chamber on the level of the albumen gland $(a)$. This entrance $(o d)$ is visible from outside, whereas the fertilisation chamber proper lies internally (Fig. 13, ci). Its communications with the accessory glands will be described in the comparative chapter. The crest that courses from the point od to the large hermaphrodite duct $(o, q)$ is the outer wall of the seminal groove going out from the fertilisation chamber. As in MacFarland's slug the large hermaphrodite duct is straight, not sacculated as in A. punctata (Eales, f. 18, od), probably due to the not quite mature state known of cervina.

A serious discrepancy between MacFarland's and our observations came forth when we searched for the communication between spermatocyst $(s)$ and fertilisation chamber, the duct of Cuvier. In our slug this duct does not exist; the sperms, introduced into the spermatocyst by the vagina $(v)$ and the duct $(s e)$ of the spermatocyst, must leave the spermatocyst on the same way and pass to the large hermaphrodite duct farther in front, where oviduct $(o)$ and vagina $(v)$ communicate. We can not even recognize a duct of Cuvier in MacFarland's figure 33, where d. C. is explained as duct of Cuvier, but, as in our preparation, is really the duct of the spermatocyst, the only communication of the latter with the female complex. We will have to return to this question in the comparative chapter.

The penis of the present specimen (Fig. 10) is protruded, so that it cannot be compared with the retracted one described by MacFarland (p. 56) and Eales (1957, p. 246). The penial sheath $(x)$ is strongly muscular, and its inner end is fastened to the body wall near its origin by the two retractors $(r)$, so that it is curled. The lining of the sheath is thrown into longitudinal folds, two of which are higher than the rest and flank the seminal groove. The epithelium is pigmented uniformly light grey with exception of the seminal groove. It is not "sprinkled with brown pigment" (MacFarland, p. 56), nor has pigmented ridges as A. brasiliana (Marcus 1955, p. 8). The penis ( $p$ ) proper is white, without pigment. It is $35 \mathrm{~mm}$ long, half of its length projecting from the male opening and forming a loop. The penis is flattened, its diameter is $0,5 \mathrm{~mm}$ in the middle and $0,8 \mathrm{~mm}$ near the pointed tip. The seminal groove courses in a spiral on the ciliated surface of the penis.

The nervous system was studied so profoundly by MacFarland (p. 45-55, t. 6-9) that we can only corroborate his findings: the completely fused cerebral ganglia and the closely united buccal ganglia (p. 51) as well as the structure of the parietal-visceral ganglion group (f. 35,42). One giant cell in the pleural ganglion has a length of $0,6 \mathrm{~mm}$, and its nucleus 
is $0,35 \mathrm{~mm}$ long. These measurements are bigger than the maxima known for nerve cells and nuclei in Aplysia (Hoffmann 1932-39, p. 862, 865).

The pleuro-visceral connectives are $25 \mathrm{~mm}$ long against $14 \mathrm{~mm}$ in MacFarland's smaller slug.

Colour, the jaws and their rods, caecum, and buccal ganglia differ in A. cervina from A. brasiliana.

\section{Discussion of Aplysia cervina}

Dr. Nellie B. Eales kindly called our attention upon A. pilsbryi, cited in the preceding synonymy, as a possible variety of $A$. cervina. Like the latter the slug from Yucatan has a wide mantle shelf. The figured 5 right and 3 left spots on the parapodia are inconspicuous warts; for the rest the colour pattern is chiefly formed by scattered stripes parallel to the foot. The available data are insufficient to evaluate Letson's species.

Though it is nearly certain that A. cervina occurs on the coast of Bahia, this is not evidenced by v. Ihering's above mentioned record. Ihering united his material from Bahia and that of MacFarland with brasiliana and separated Dall \& Simpson's as the true cervina. As Engel \& Hummelinck (1936, p. 14) said, Ihering did not succeed to justify his opinion. The same holds true for Ihering's separation of brasiliana and livida. He distinguished, for example (p. 136), the breadth of the shell as $71-75 \%$ of its length in livida and $65-68 \%$ in brasiliana. Evidently he had only examined few specimens, because we found $66,7-84,6 \%$ in brasiliana (Marcus 1955, p. 6), to which livida is synonymous (Eales 1957, p. 246).

The variation of this shell-proportion is considerable in several species of Aplysia. In cervina it is from $63,3 \%$ (Dall \& Simpson) and $66,7 \%$ (MacFarland) to $75,5 \%$ (the slug of the present description) and 76,2\% (Engel \& Hummelinck). According to these last authors (p. 11-12) it is from $60-87 \%$ in $A$. dactylomela and $58,4-87,5 \%$ in parvula (p. 21). In A. (Tullia) Juliana the proportion varies from $56,3-100 \%$ (Engel \& Eales 1957, p. 86,92).

Only the first short description of A. cervina was based on several (9) slugs. The later records, including the present one, are founded on single animals. Nevertheless MacFarland's exposition was so complete that the species became well defined. Our sea-hare was in good alimentary condition, and neither the weather in the preceding days nor the locality where the animal was found were exceptional. Hence we cannot explain, why after many collecting trips only now the first specimen has been taken. It is true that also adult $A$. dactylomela were rarely observed at the sheltered localities where we collect. Also A. juliana is far less common in the upper littoral of the coast of São Paulo than A. brasiliana, whose ecological range is wide. On the day when we found our first cervina, several specimens of brasiliana were seen in the neighbourhood. 


\section{Key for the classification of the Brazilian sea-hares}

The key is intended for the identification of adult animals, living or preserved in formalin, without dissection. Young slugs and such that have remained in alcohol for many months or years can only be classified by dissection.

1 On the sides black or sepia-brown rings on the much lighter ground colour ... dactylomela Rang 1828.

- No distinct lateral rings... 2 .

2 Parapodia fused high up posteriorly ... 3.

- Parapodia joined low down posteriorly ... 4 .

3 Besides gliding the siug moves after the fashion of a looper caterpillar; alive it has a posterior foot disc. Holding the parapodia apart with the fingers one sees the moderately convex mantle shelf. The mantle foramen is usually large, but much less than one third of the subjacent shell. Neither this aperture nor other organs bordered with black ... juliana Quoy \& Gaimard 1832.

- Without looping movements and foot disc, though sometimes attached only by the tip of the tail. Mantle shelf wide, highly convex. In the variety nigrocincta Martens 1880, the only form we have seen (Eales 1957, p. 251, mentions two earlier Brazilian specimens), the outer border of the parapodia is black. There are also black marks on mouth, tentacles, rhinophores, siphon, border of the foot, and tip of the tail, not always present in one and the same specimen ... parvula Mörch 1863.

4 Very dark or light or intermediate tones. When light, a network of dark pigment is sometimes condensed here and there to multiform spots ... brasiliana Rang 1828.

- Greyish, not uniformly dark. On each side from many (about 60) to few (8-10) dark, round spots independent from the net of pigment ... cervina Dall \& Simpson 1901.

\section{Comparison of the reproductive organs}

We examined about 12 -cm-long specimens of A. brasiliana, A dactylomela and A. (Tullia) juliana, of brasiliana also several smaller ones. The length of the reproductive organs from the fundus of the mucus gland to the spermathecal duct is $30-40 \mathrm{~mm}$ in the $12 \mathrm{~cm}$ long slugs. The proportions of the various parts are almost the same in smaller and bigger animals (Fig. 11, 15). The mucus gland $(d)$ is thicker in adult slugs than in younger ones. Also the spermatheca $(t)$ becomes more extended, owing to an increased dilatation of its duct $(c s)$, which shortens thereby. The ental portion of the glandular oviducal compartment (o) of the large hermaphrodite duct is reddish brown in all examined species. In young slugs of brasiliana it is striped longitudinally (Fig. 15) as in cervina (Fig. 9), due to internal folds; in old brasiliana (Fig. 11) it appears trans- 
versely striped, and in old dactylomela (Fig. 12) and juliana (Fig. 14), nearly homogeneous. The sacculations that occur in the entire posterior portion of the large hermaphrodite duct in A. punctata (Eales 1921, p. 61) are in brasiliana only developed in the anterior part of this portion. A muscle and on the opposite side an internal fold, the first fold of our terminology (Fig. 11, ia), occur here, and between them the sacculations.

Ductules emerging from the hermaphrodite gland or ovotestis (Eales 1921, p. 59) form the hermaphrodite duct or common genital duct, coming from both sides. The duct is thin, while it courses on the gonad, and widens when it leaves it. The widened, sinuous part is the thin-walled ampulla $(h)$ or little hermaphrodite duct (Eales), followed by a narrower part, the spermoviduct ( $l$ ), Eales' loop of the little hermaphrodite duct.

Cilia occur in the ampulla as well as in the spermoviduct. They are especially long on one side of the internal fold (Eales 1921, p. 64, f. 20 $d$, lp) that appears in the spermoviduct (Fig. 17). There is a band of cyanophilous glands on the same side of this fold, and these glands can be followed through the fertilisation chamber $(c i)$ to the seminal groove $(q)$ in the large hermaphrodite duct.

The spermoviduct enters (od) the fertilisation chamber, which opens into the large hermaphrodite duct. The chamber communicates several times with the albumen gland $(a)$, the winding gland $(w i)$, and the mucus gland $(d)$. The diagram of this region (Fig. 13) was drawn from the preparation of $A$. dactylomela and completed with sections of A. brasiliana. It refers likewise to $A$. juliana and $A$. cervina. The sections show that the blue staining glands, whose stripe characterizes the course of the sperms, are not developed in the albumen, winding, and mucus gland. These accessory glands are purely female organs. In this connection Mazzarelli's denomination (1889) separation chamber for Eales' fertilisation chamber may be remembered. The separation, it is true, refers only to the sperms, excluded from the passage through the accessory female glands, not to the eggs, which in addition to their own use all the male ways too.

According to Eales (1921, p. 70) the eggs receive their coating of albumen discharged by the albumen gland into the fertilisation chamber. Then they enter the winding gland. In the preserved slug the latter cannot be unrolled as a simple tube, but forms various pouches connected with one another by wide and thick-walled stretches. These connective tubes communicate with the albumen and the mucus gland. The connection (Fig. 9, vi) between winding gland and mucus gland is visible from outside in most preparations. The mucus gland $(d)$ is tubular, and its wall consists of two pairs of bands, alternating smooth and with high folds. The tube runs backwards in two coils, returns forward along itself, and opens into the fertilisation chamber.

The large hermaphrodite duct lodges oviduct (o), seminal groove $(q)$, and vagina $(v)$; the latter communicates with a spermatheca $(t)$ and a spermatocyst $(s)$. The fundus of a more or less semiglobular gland, the 
clustered gland (b), "résé:voir séminal" (Guiart 1901, f. 92, RS) or bursa seminalis (Eales 1921, f. 18, $20 \mathrm{~b} . \mathrm{sem}$.) is located between the bend of the spermathecal duct $(c s)$ and the vagina $(v)$. It opens with a broad transverse cleft distinctly farther inwards between the oviducal and the vaginal compartment. The slit-like lumen of the clustered gland (Fig. 18) bears numerous small glandular diverticula on its ventral side. The function of this organ is secretory, it does not store sperms. Though the folded atrial gland of Phyllaplysia engeli and others (Marcus 1957, p. 62, f. 15, 16 ae) is nearer to the common genital opening it seems comparable with the clustered gland of Aplysia.

Along the two outer thirds of the large hermaphrodite duct (Fig. 16) its right oviducal $(o)$ and left vaginal $(v)$ compartment are incompletely separated by a fold, the first internal fold $(i a)$. The seminal groove $(q)$ courses within the oviducal compartment. The point where the second internal fold (is) begins with a thickening of the wall of the oviducal compartment is externally recognizable (Fig. 11, 12). It is marked by the outer end of the reddish brown colour mentioned above for the ental part of the oviducal portion.

The second fold lies farther to the right and is stronger than the more left-sided first fold. Both folds appear externally as smooth bands (Fig. 14, ia, is). Farther entally the right, bigger fold coalesces with the opposite wall of the large hermaphrodite duct, thus separating oviducal $(o)$, and vaginal $(v)$ tube completely. The latter forms the stalk $(s e)$ of the spermatocyst $(s)$. The first internal fold continues into this stalk or duct and flattens here (see Fig. 16, levels 9-11). The epithelium of the spermatocystal duct is thrown into folds, and the diameter of the duct widens a little in the middle of its course in $A$. cervina (Fig. 8, se) and sometimes in brasiliana. The wall of the spermatocyst is thin, even in young, empty stage.

The second fold (is) closes the right side of the vagina $(v)$ and the left side of the innermost part (Fig. 13,o) of the large hermaphrodite duct. The female function of this section is only oviducal. The seminal groove (q) runs along its left wall. The large hermaphrodite duct is the only communication of the fertilisation chamber (ci) with the common genital aperture. In the 4 examined Brazilian species of Aplysia the vagina goes on as the duct of the spermatocyst. A second connection of the vagina farther inwards to the fertilisation chamber does not exist, though it has been described by MacFarland (1909, p. 36) for A. dactylomela and drawn by Eales (1921, f. 20) for A. punctata. Sheets of connective tissue envelop the various organs of this region, but no pore or duct unites the lumina of the spermatocyst and the fertilisation chamber. Neither is there a long canal, the so-called duct of Cuvier, between the two organs as described by Mazzarelli (1889, p. 332), whose diagram (p. 331) of Mediterranean species is similar to Cuvier's figure (1803). Mazzarelli understood this canal as male duct. Such a duct, however, does not exist, but only a furrow, the seminal groove $(q)$, which passes from the fertilisation chamber into the large hermaphrodite duct (Fig. 13). 
Thus all our 4 species of Aplysia have no "uterine duct", as the communication between the vaginal spermatocyst and the vagina with the oviduct within the accessory glands is called in the Nudibranchiata. The foreign sperms leave the spermatocyst by its duct, enter the vagina and gain the oviducal compartment of the large hermaphrodite duct in the region of the overlapping first and second internal folds. Once in the oviduct they may descend and reach the fertilisation chamber.

\section{R E S U M O}

De Aplysia cervina (Dall \& Simpson 1901) conhecia-se, do Brasil, um exemplar de Maceió. Mais um, quase maduro, foi colhido no eulitoral da ilha de São Sebastião. Enquanto vivente, tinha comprimento de $10 \mathrm{~cm}$. A espécie distingue-se, de $A$. brasiliana, pelas manchas escuras redondas (Fig. 1), pela forma das mandíbulas (Fig. 4) e dos bastonetes (Fig. 5) que as compõem, pelo ceco (Fig. 7, c) encurvado e dirigido mais transversal que longitudinalmente, e pela aproximação dos gânglios bucais. A rádula não oferece seguros critérios sistemáticos. A chave para determinar as 5 espécies de Aplysia, ocorrentes na costa brasileira, possibilita classificação de espécimes adultos, viventes ou conservados em formalina, sem dissecção.

A comparação dos órgãos reprodutivos de A. brasiliana, dactylomela, juliana, e cervina mostra que, para a fecundação dos óvulos, os espermatozóides saem do espermatocisto $(s)$ pelo duto $(s e)$ dêste. Daí passam para a vagina $(v)$. Sobem nela até à região em que os compartimentos vaginal e oviducal (o) se comunicam. Entram no último e descem nêle para a câmara de fertilização (ci). Duto uterino (duto de Cuvier) ou comunicação entre vagina e a dita câmara inexiste. A bursa seminal (b) é comparável à glândula atrial de Phyllaplysia (Marcus 1957, f. 15, 16, ae).

Cuvier, G.

\section{R E F E R E N C E S}

1803. Mémoire sur le genre Laplysia, vulgairement nommé Lièvre marin, sur son anatomie, et sur quelques-unes de ses espèces. Ann. Mus. Hist. Nat. vol. 2, p. 287-314, t. 1-4 (52-55). Paris.

DALL, W. H. \& Simpson, C. T.

1901. The mollusca of Porto Rico. Bull. U. S. Fish. Comm. 1900, part 1, p. $351-524$, t. 53-58. Washington, D. C.

EALES, N. B.

1921. Aplysia. L. M. B. C. Memoir 24, VIII +84 p., 7 t. Liverpool (University Press).

1957. Revision of the species of Aplysia of the Muséum National d'Histoire Naturelle. Bull. Mus. Hist. Nat., sér. 2, vol. 29, n. ${ }^{\circ} 3$, p. 246-255. Paris.

Engel, H. \& Eales, N. B.

1957. The species of Aplysia belonging to the subgenus Tullia Pruvot Fol, 1933: On a generic character in statu nascendi. Beaufortia, vol. 6, n. ${ }^{\circ} 69$, p. 83-114. Amsterdam.

Engel, H. \& Hummlinck, P. W.

1936. Über westindische Aplysiidae und Verwandte anderer Gebiete. Capita Zool., vol. 8, p. 1-75. 's-Gravenhage.

Guiart, J.

1901. Contributions à l'étude des Gastéropodes Opisthobranches, etc. Mém.

Soc. Zool. France, vol. 14, p. 5-219, t. 1-17. Paris. 
HoFfMANN, H.

1932-39. Opisthobranchia Bronn, Kl. Ordn., vol. 3, 2. Abtlg., 3. Buch, Teil 1, $\mathrm{XI}+1247$ p., 1 t. Leipzig (Akadem. Verlagsgesellschaft).

IHERING, H. v.

1915. Die Opisthobranchien der brasilianischen Küste. Nachr. Bl. d. Deutsch. Malakozool. Ges., vol. 47, p. 133-143. Frankfurt a. M.

LETson, E. J.

1898. Description of a new Tethys (Aplysia). Proc. Acad. Nat. Sci. 1898, p. 193 , t. 8. Philadelphia, Pa.

MacFarland, F. M.

1909. The Opisthobranchiate Mollusca of the Branner-Agassiz Expedition to Brazil. Stanford Univ., Publ. Univ., ser. n. ${ }^{\circ}$ 2, p. 1-104, t. 1-19. Stanford, Cal.

Marcus, E. \& E.

1955. Sea-Hares and Side-gilled Slugs from Brazil. Bol. Inst. Ocean., vol. 6, p. 1-49, t. 1-8. São Paulo (1957).

1957. On Phyllaplysia engeli. Basteria, vol. 21, p. 53-66. Leiden.

Mazzarelli, G. F.

1889. Intorno all'Anatomia dell'apparato riproduttore delle Aplysiae del Golfo di Napoli. Zool. Anz. 12 Jahrg., p. 330-336. Leipzig.

\section{EXPLANATION OF ABBREVIATIONS USED IN THE FIGURES}

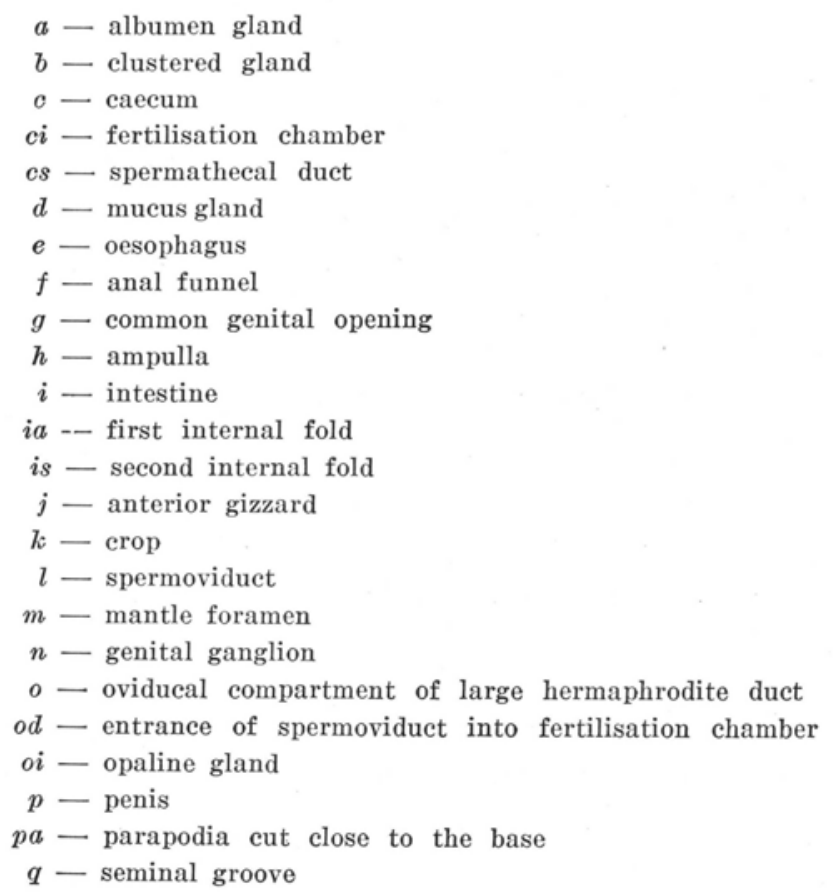




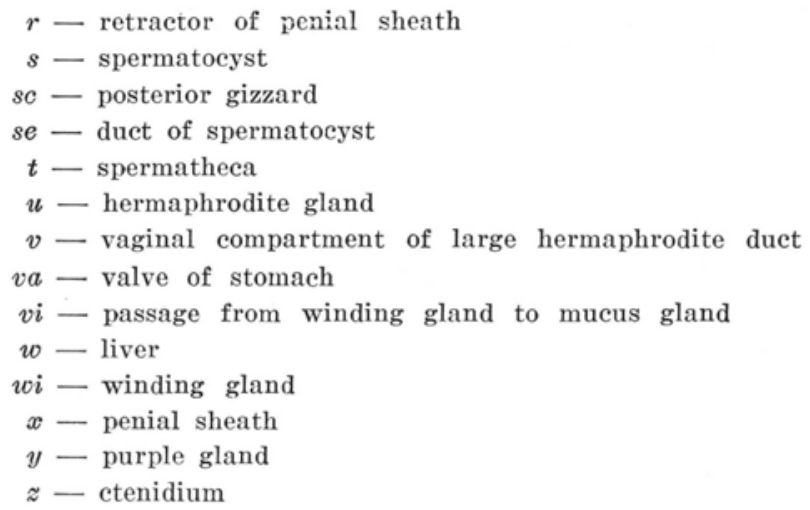




\section{P LA T E I}

\section{Aplysia cervina Dall \& Simps.}

Fig. 1 - Left side of preserved slug.

Fig. 2 - Mantle and pallial organs. Parapodia cut and edge of mantle reflected.

Fig. 3 - Outline of shell.

Fig. 4 - Jaw plates.

Fig. 5 - Rodlet of jaw plate.

Fig. 6 - Radula: rhachidian plate and several laterals and marginals. 

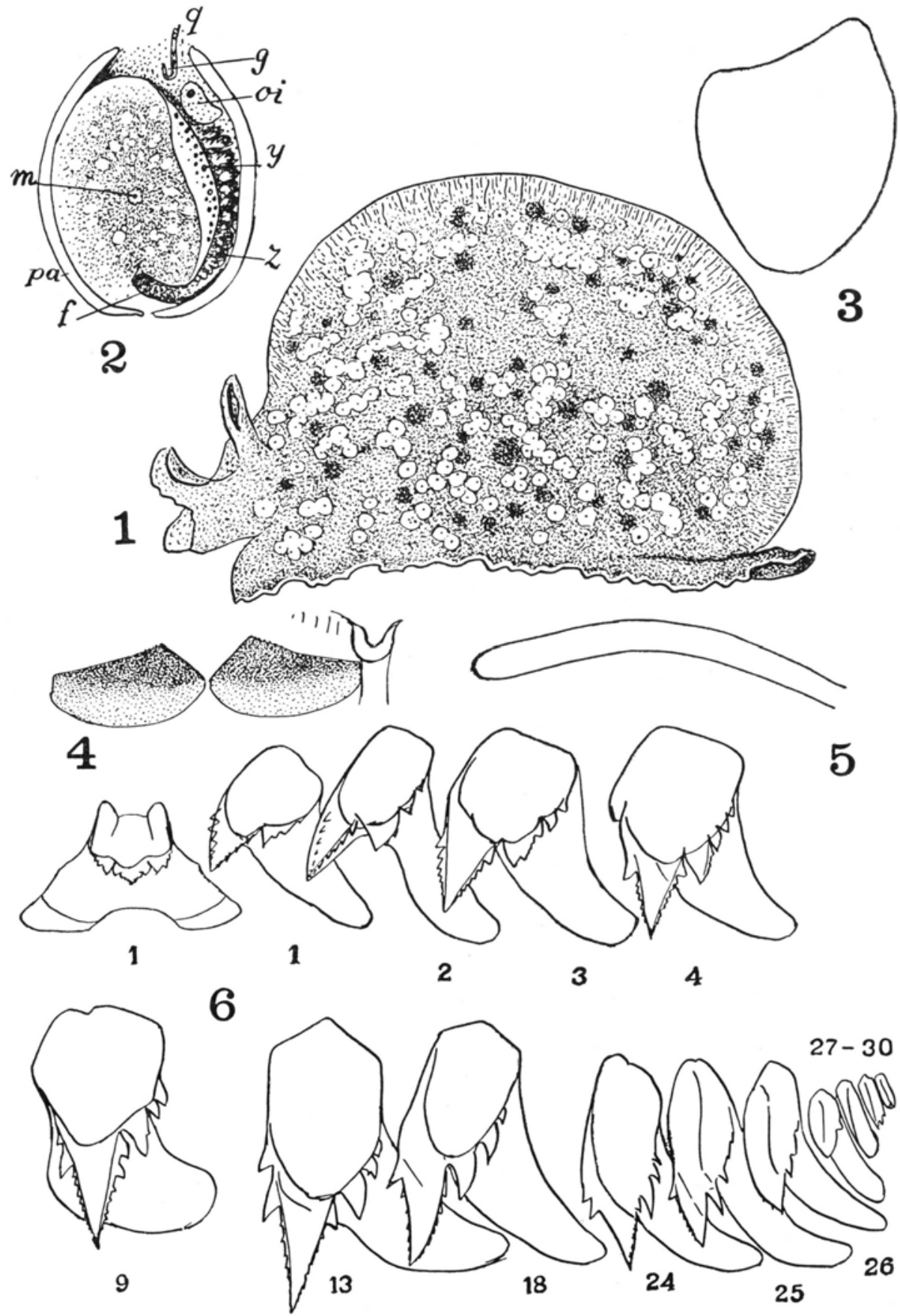
Aplysia cervina Dall \& Simps.

Fig. 7 - Diagram of digestive tract.

Fig. 8-Reproductive organs, dorsal view.

Fig. 9 - Reproductive organs, ventral view.

Fig. 10 - Male copulatory organ. 


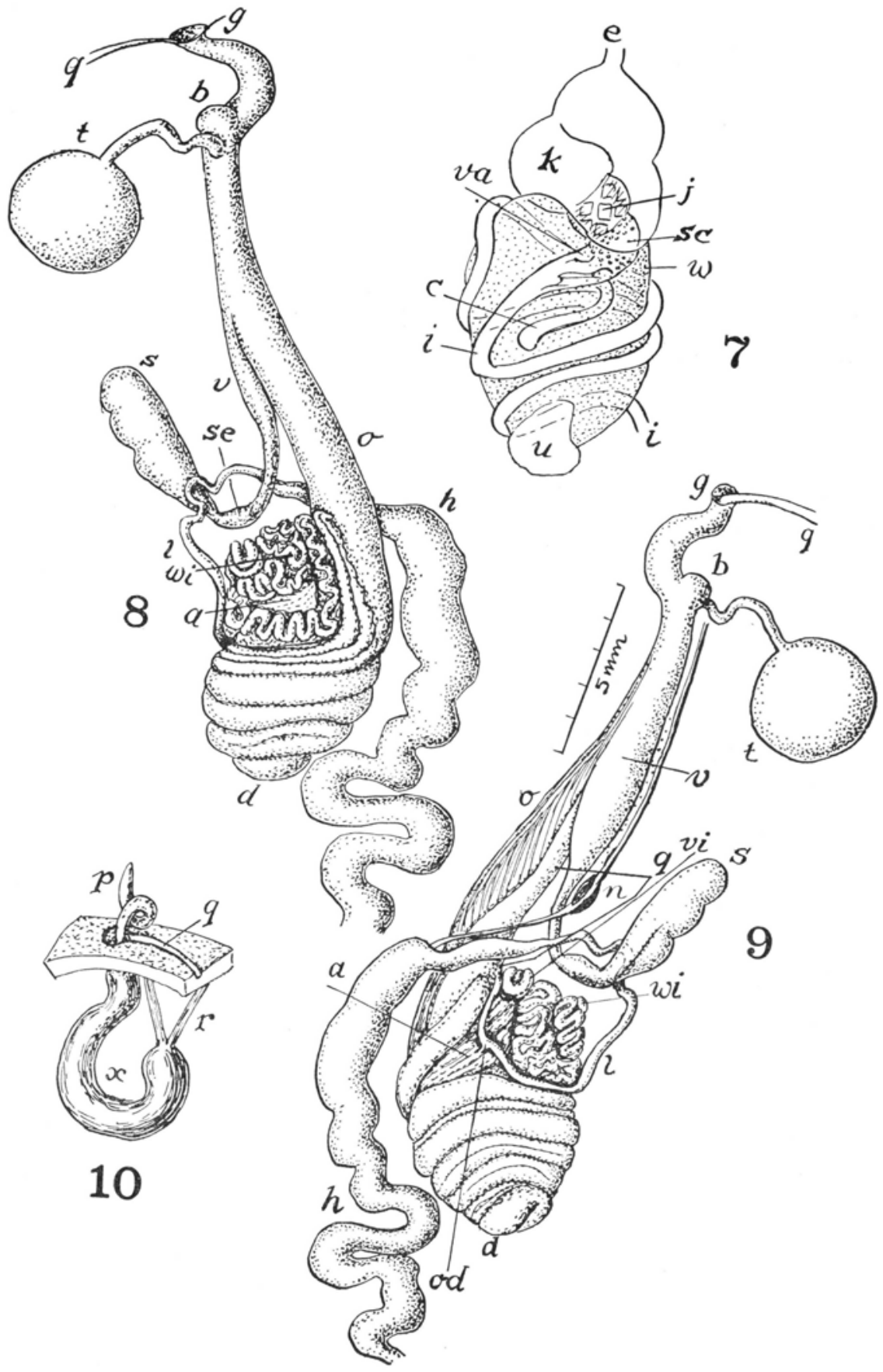




\section{P L A T E I I I}

\section{Aplysia brasiliana Rang}

Fig. 11 - Reproductive organs of adult slug, ventral view.

\section{Aplysia dactylomela Rang}

Fig. 12 - Reproductive organs of adult slug, ventral view.

Fig. 13 - Diagram of central part of efferent ways of generative system; ventral view.

Aplysia (Tullia) juliana Q. \& G.

Fig. 14 - Reproductive organs of adult slug, dorsal view. 


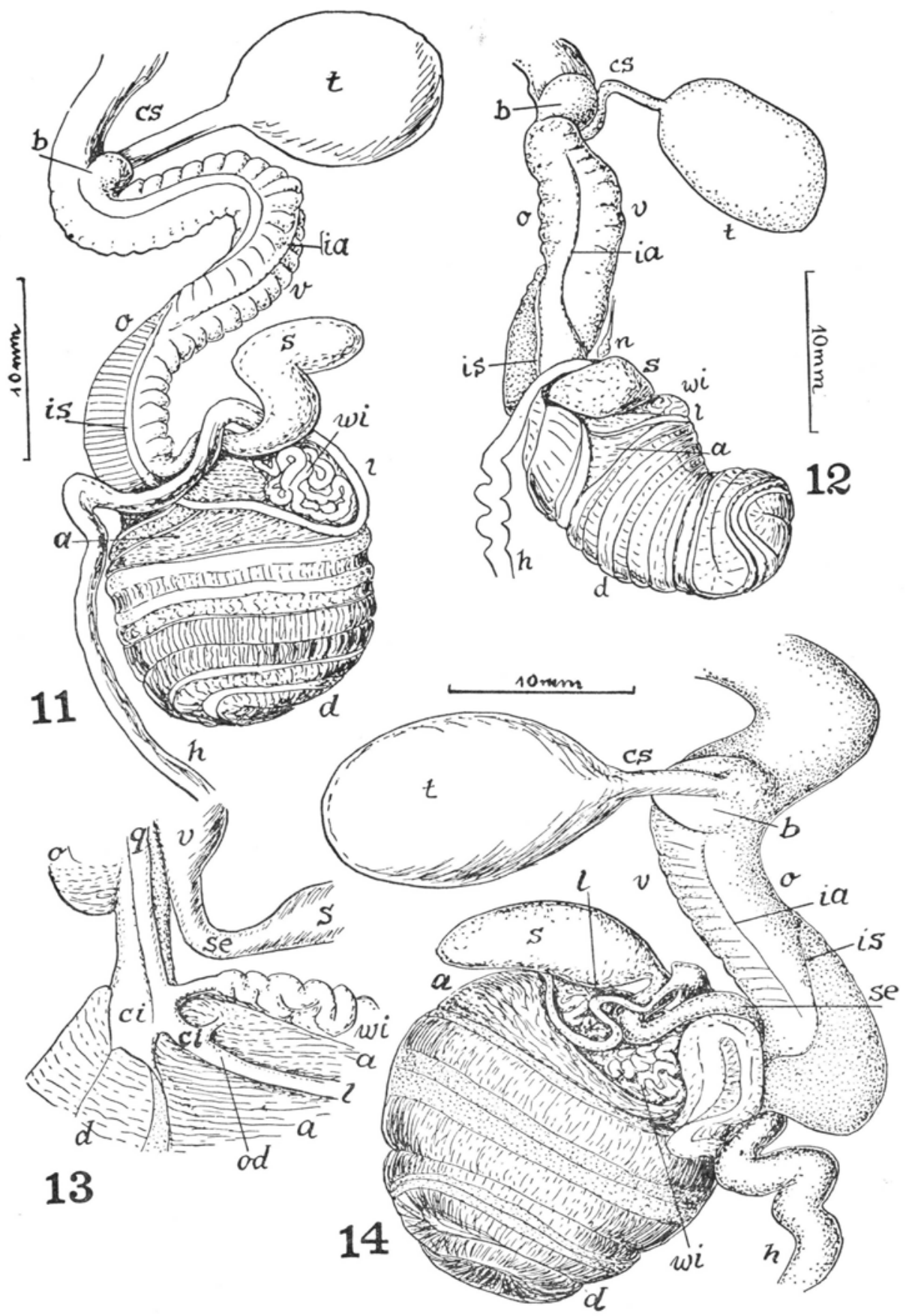




\section{PLATE I V}

\section{Aplysia brasiliana Rang}

Fig. 15 - Reproductive organs of not yet mature slug, dorsal view.

Fig. 16 - Diagram of large hermaphrodite duct, ventral view. The numbers 1-11 indicate the $\mathrm{mm}$. behind the point, where the duct leaves the body cavity.

Fig. 17 - Transverse section of spermoviduct.

Fig. 18 - Transcreve section of clustered gland lying between second and third section in Fig. 16. 


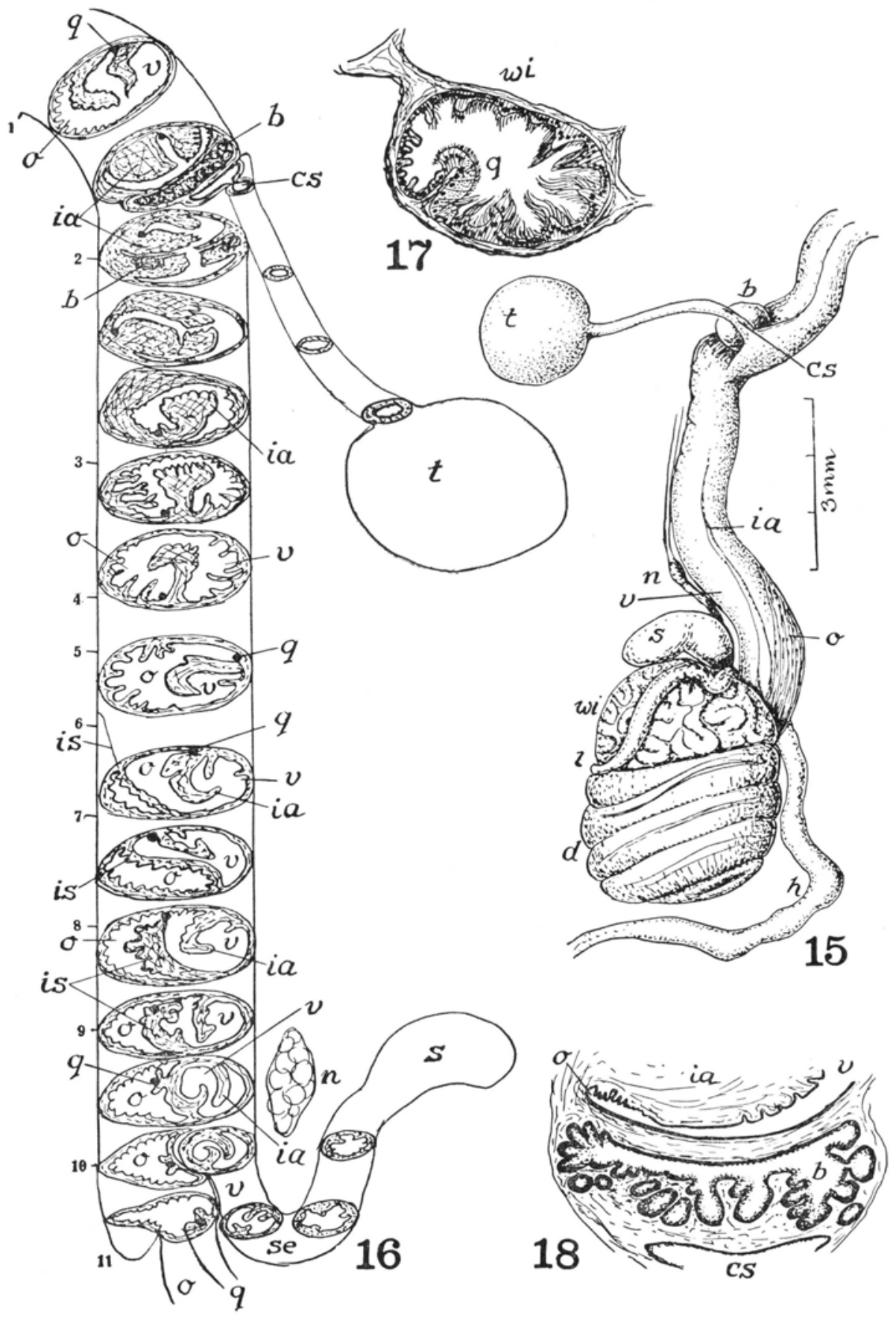

